\title{
Demographic Profile of Blindness in Patients attending Tertiary Eye Care Centre in Central India
}

\author{
Sharma B ${ }^{1}$, Gupta $R^{2}$, Anand $R^{3}$, Rajput $M^{4}$ \\ ${ }^{1}$ Dr Bhavna Sharma, Assistant Professor in Ophthalmology, ${ }^{2}$ Dr Rachna Gupta, Associate Professor in Ophthalmology, ${ }^{3}$ Dr \\ Reena Anand, Professor in Ophthalmology, ${ }^{4}$ Dr Mukesh Rajput. All are affiliated with Gandhi Medical College, Bhopal, India
}

Address for correspondence: Dr Rachna Gupta, Email: drrachnagupta2k@gmail.com

\begin{abstract}
Introduction: Blindness is a social curse $\&$ more than $80 \%$ cases of blindness are due to avoidable causes. In India greater part of blind population resides in rural area, because they often get very late medical attention for ocular problem due to varied reasons like poverty, ignorance and less availability of Medical care. Methods: This study was done to evaluate the recent epidemiological trends, clinical profile in blind patients \& causes of blindness in patients attending a tertiary eye care centre of central India .Other references for evaluation were - associated risk factors in causation of blindness, management strategy for blindness \& to evaluate rehabilitation services for blind patients. Results: In our study maximum no of blind patients were from rural area. Maximum numbers of Patients were from Lower class (67.8 \%) followed by Middle class (26.8\%). 38.4 \% of blind patient were farmer by occupation followed by labourer in $24.1 \%$ of patients. $31.6 \%$ of total blind were illiterate. $53 \%$ were male and $47 \%$ were female. Conclusion: The higher prevalence in the rural areas is possibly related to less availability of eye care services in these areas compared with the urban area.
\end{abstract}

\section{Introduction}

Blindness is a devastating physical condition with deep emotional implications. There are many low vision and blind people worldwide, and there is a considerable amount of data available on the prevalence of low vision and blindness in many parts of the world. The data, however, vary significantly from one region to another. In 1995, the World Health Organization (WHO) Task Force on data on blindness estimated that there were 37.1 million blind people worldwide, indicating a global prevalence of 0.7 percent $^{1}$. According to that report, theprevalence values range from $0.3 \%$ in the developed countries to $1.4 \%$ in SubSaharan African countries.

Manuscript received: $16^{\text {th }}$ Aug 2013

Reviewed: 26 $6^{\text {th }}$ Aug 2013

Author Corrected: $29^{\text {th }}$ Aug 2013

Accepted for Publication: $10^{\text {th }}$ Oct 2013
Visual impairment is also unequally distributed across age groups, gender, socioeconomic status, rural or urban ${ }^{2}$. This study was done to evaluate the recent epidemiological trends in blindness profile $\&$ causes of blindness in patients attending a tertiary eye care centre of central India, with reference to associated risk factors in causation of blindness.

In India greater part of blind population resides in rural area. This is because urban population is more educated, has better sense of hygiene

and has easy access to ophthalmologist, whereas rural population often gets medical attention for ocular problem very late due to varied reasons like poverty, ignorance, and long distance from specialised medical centre. 


\section{Methods}

This study was a longitudinal prospective nonrandomised in nature. It was carried out to evaluate the demographic profile of blind patients attending eye OPD of Hamidia Hospital \& Regional institute of ophthalmology Bhopal, India.

Blind patients were examined in detailed and after careful evaluation of blind patients appropriate intervention was done in form of surgical rehabilitation or vocation rehabilitation at deaf and blind school and blind relief association of Bhopal.

In this study patients attending eye OPD Hamidia hospital Bhopal were examined and Blind patients were selected according to WHO international classification \& criteria of blindness $^{3}$ (vision $<3 / 60$ in better eye with best corrected visual acuity adapted from international statistical classification of diseases and related health problem, tenth revision Geneva WHO,1992) of all age group and sex, religion, mother tongue, occupation.

All appropriate and relevant investigations were done to evaluate cause of blindness. Patients in category of unavoidable blindness and Patients not improving with medical and surgical means were send for rehabilitation.

Patients were evaluated in following heads: Age, Sex, Marital status, Religion, Dietary habits, Residence, occupation, education status, Monthly income of Patient or family. Careful history was also taken with regards to blindness in family, economic status, psychological reaction to blindness, age of onset of blindness, history regarding consultation was taken from qualified doctor. Detailed examination of eye was conducted aided with Slit lamp examination, along with Intraocular pressure \& Fundus examination.

\section{Results}

Results were discussed in tabulated form.

Table No 1: Showing distribution of Blinds according to their age and sex

\begin{tabular}{|c|c|c|c|c|c|c|c|c|c|}
\hline S. No & Sex & $\begin{array}{c}\text { Up to 10 } \\
\text { yrs - \% }\end{array}$ & $\begin{array}{c}\mathbf{1 1 - 2 0} \\
\text { yrs - \% }\end{array}$ & $\begin{array}{c}\mathbf{2 1 - 3 0} \\
\text { yrs - \% }\end{array}$ & $\begin{array}{c}\mathbf{3 1 - 4 0} \\
\text { yrs - \% }\end{array}$ & $\begin{array}{c}\mathbf{4 1 - 5 0} \\
\text { yrs - \% }\end{array}$ & $\begin{array}{c}\mathbf{5 0 - 6 0} \\
\text { yrs - \% }\end{array}$ & $\begin{array}{c}\text { Above 60 } \\
\text { yrs - \% }\end{array}$ & $\begin{array}{c}\text { Total } \\
\text { \% }\end{array}$ \\
\hline $\mathbf{1 .}$ & Male & 71 & 67.7 & 70 & 40.6 & 59.4 & 47.7 & 47 & 52.7 \\
\hline $\mathbf{2 .}$ & Female & 29 & 33.3 & 30 & 59.4 & 40.6 & 52.3 & 53 & 47.3 \\
\hline & total & 100 & 100 & 100 & 100 & 100 & 100 & 100 & 100 \\
\hline
\end{tabular}

In our study of 364 blind patients, 53\% were male and 47\% were female. Maximum no of blind patients (42.5\%) were in age group of 60 yrs and above. Male: female ratio was 1.11:1.

Table No 2: Showing distribution of blind according to their regional variation

\begin{tabular}{|c|c|c|c|c|}
\hline S. No. & Region & Male-\% & Female-\% & Total-\% \\
\hline $\mathbf{1}$ & Rural & 82.3 & 81.4 & 81.8 \\
\hline $\mathbf{2}$ & Urban & 17.7 & 18.6 & 18.2 \\
\hline & Total & 100 & 100 & 100 \\
\hline
\end{tabular}


Maximum Number of blind patients were from rural area (81.8\%) and rest of the patients (18.2\%) were from urban area. Ratio of rural and urban population was $4.5: 1$.

Table No 3: Showing distribution of blinds according to their socioeconomic status

\begin{tabular}{|c|c|c|c|c|c|c|}
\hline S. No & $\begin{array}{c}\text { Socioeconomic } \\
\text { class }\end{array}$ & $\begin{array}{c}\text { Up to 20 } \\
\text { yrs-\% }\end{array}$ & $\begin{array}{c}\mathbf{2 0 - 4 0} \\
\text { yrs-\% }\end{array}$ & $\begin{array}{c}\mathbf{4 0 - 6 0} \\
\text { yrs-\% }\end{array}$ & $\begin{array}{c}\text { Above60 } \\
\text { yrs-\% }\end{array}$ & $\begin{array}{c}\text { Total } \\
\text { yrs-\% }\end{array}$ \\
\hline 1. & Upper & 0.2 & 0.5 & 1.2 & 2.5 & 4.9 \\
\hline 2. & Middle & 3.4 & 4.2 & 7.6 & 8.3 & 26.8 \\
\hline 3. & Lower & 7.2 & 11.2 & 18.6 & 32.4 & 67.8 \\
\hline & Total & 10.7 & 15.9 & 27.5 & 46.3 & 100 \\
\hline
\end{tabular}

According to kuppuswamy classification ${ }^{4}$, three categories of socioeconomic status were taken in consideration. In our observation number of blind patients in upper, middle and lower class were $4.9 \%, 26.8 \%$ \& $67.8 \%$ respectively.

Table No 4: Showing distribution of blinds according to their occupation

\begin{tabular}{|c|c|c|c|}
\hline S. No & Occupation & Male $\%$ & Female \\
\hline 1. & Student & 3.8 & 2.1 \\
\hline 2. & Service class & 6.0 & 1.0 \\
\hline 3. & Farmer & 18.6 & 19.7 \\
\hline 4. & Labourer & 13.1 & 9.9 \\
\hline $\mathbf{5 .}$ & Businessmen & 2.1 & 0.0 \\
\hline $\mathbf{6 .}$ & Beggar & 3.2 & 13.7 \\
\hline $\mathbf{7 .}$ & Not working & 5.4 & 47.3 \\
\hline
\end{tabular}

Most number of patients were labourer and former by occupation.

Table No 5: Showing distribution of blinds according to their education status

\begin{tabular}{|c|c|c|c|c|}
\hline S. No & Educational status & Male \% & Female \% & Total \% \\
\hline $\mathbf{1 .}$ & Illiterate & 11.5 & 20.6 & 31.6 \\
\hline $\mathbf{2 .}$ & Primary & 16.7 & 11.7 & 25.7 \\
\hline $\mathbf{3 .}$ & Middle & 9.7 & 9.1 & 18.1 \\
\hline $\mathbf{4 .}$ & High school & 7.7 & 4.9 & 12.7 \\
\hline $\mathbf{5 .}$ & College & 9.7 & 2.6 & 12.2 \\
\hline $\mathbf{6 .}$ & Total & 52.5 & 47.5 & 100 \\
\hline
\end{tabular}

Blindness was more commonly associated with lower literacy rate. It is more common in Illiterate and primary educated person. 
Table No 6: Distribution of blinds according to the cause of blindness

\begin{tabular}{|c|c|c|c|c|}
\hline S. No. & Cause of blindness & Male & Female & Total \\
\hline $\mathbf{1 .}$ & Cataract & 25.2 & 24.2 & 49.45 \\
\hline $\mathbf{2 .}$ & Glaucoma & 3.3 & 3 & 6.3 \\
\hline $\mathbf{3 .}$ & Trauma & 1.9 & 1.0 & 2.9 \\
\hline $\mathbf{4 .}$ & Corneal disorder & 9.9 & 7.6 & 17.5 \\
\hline $\mathbf{5 .}$ & Vitreoretinal disorder & 4.9 & 3.3 & 8.2 \\
\hline $\mathbf{6 .}$ & Staphyloma & 2.1 & 2.1 & 4.2 \\
\hline $\mathbf{7 .}$ & Others & 7.4 & 7.7 & 15.1 \\
\hline
\end{tabular}

Most common cause of blindness in this series was cataract (50\%). Other common preventable causes include Glaucoma and Trauma.

It is worth mentioning here that maximum number of patients $(82.3 \%)$ were in the category of avoidable blindness. As per NPCB survey (2006-07) nearly $80 \%$ of blindness in India is preventable and another 5\% is curable.

In our study appropriate intervention was done by medical and surgical means. Most common being cataract surgery. Out of $82.3 \%$ of blind patients $75.25 \%$ achieved good improvement in vision ( $>4$ lines on Snellens chart).

Remaining patients were sent for rehabilitation. Hence timely appropriate medical or surgical intervention can go a long way in management and prevention of blindness.

\section{Discussion}

The present study comprises 364 blind patient attended Outpatient department of Regional Institute of ophthalmology at Hamidia hospital, Bhopal, India

\section{Regional variation}

In our study maximum no of blind patients were from rural area $(81.8 \%)$. Ratio of rural and urban population was 4.5:1. Though this finding is not surprising, it does indicate the poor eye care scenario in the rural areas.

The higher prevalence in the rural areas is possibly related to less availability of eye care services in these areas compared with the urban areas. Similar result were also found in many other studies ${ }^{5,6,7}$

Socioeconomic Status
There is a lot of economic burden in a community or a nation due to the presence of large number of blind persons. These people who are not capable of productive work,

especially blind children need guidance and economic support to become self-dependent. Similarly elderly blinds need special care.

In our study blind patients were categorised into three socioeconomic classes according to kuppuswamy classification ${ }^{4}$ based on education, occupation, and family monthly income.

$4.9 \%$ blind patients were from upper class, $25.8 \%$ belonged to middle socioeconomic class and $67.8 \%$ belonged to lower socioeconomic class. 
Thus by above study we observe that lower socioeconomic class population had a significant relative risk (4.7) for development of blindness as compare to higher socioeconomic class. A study done by Dandona R et al ${ }^{8}$ concluded that blindness is more common in low socio economic status population.

The Andhra Pradesh Eye Disease Study ${ }^{9}$ reported that the odds of having blindness increased with decreasing monthly per capita income.

Those belonging to lower socioeconomic strata have five times higher risk of having blindness, compared with those belonging to the upper socioeconomic status. Various other studies $^{5,6,7}$ also suggested that blindness is more common in low socioeconomic group .

\section{Educational Status}

Education, in terms of years of schooling, has also been assessed as an independent predictor for the risk of blindness, directly relating to economic status.

In this study incidence of blindness was much more common in illiterate and low educated group. $32.14 \%$ blind patients were illiterate \& $42.3 \%$ blind patients were educated up to primary.

Thus by above study we observe that non-educated group had a significant higher risk (1.5 times) for development of blindness as compare to educated group.

A Population based cross-sectional study done by Rohit C et al ${ }^{10}$ found that $58 \%$ blinds were illiterate, $35.2 \%$ blind were educated up to school class and only $6.6 \%$ blind were educated up to collage level.

Global data on blindness by Thylefors $\mathrm{B}^{11}$ suggested, that the prevalence of blindness is inversely related to education status of population of any region. Around three times higher risk of blindness has been reported in those with no schooling compared with those with schooling in studies from India, China, and Nepal.

\section{Occupation}

Blind patients as distributed according to their occupation, we found that $38.4 \%$ blinds were farmer, $24.1 \%$ were labourers, $7.1 \%$ were service class and, 9.4\% were student, $3.7 \%$ were beggar, $2.1 \%$ were businessman and $19.1 \%$ were in miscellaneous group (including house wife and not working).

Thus by above study we observed that farmer and labourer group had more risk for development of blindness as compare to other group. Similar result were also found in a Population-based cross-sectional study ${ }^{10}$

\section{Causes of blindness}

In our study major cause of blindness was cataract (49.45\%) followed by refractive error (14.2) \& corneal blindness (17.5). Various other studies ${ }^{5,6,7,8}$ have shown that cataract is the most common cause of blindness in India.

Other causes vary from region to region depending upon population structure, socioeconomic condition, Environment, Industrialization, education and resources available to community.

In our study corneal blindness is of major concern because this was second most common cause of blindness. As per NPCB survey done in 2006-07 corneal blindness was forth most common cause of blindness. VenkataG et $\mathrm{al}^{7}$ suggested that most common cause of blindness was cataract $(62.4 \%)$, followed by refractive errors $(19.65 \%)$, glaucoma $(5.83 \%)$.

The Aravind Comprehensive Eye Survey ${ }^{12}$ concluded that age-related cataract was the most common potentially reversible blinding disorder $(72.0 \%)$ among eyes presenting with blindness.

\section{Conclusion}

In this study we observed that incidence of blindness was $1.38 \%$. Male and female ratio was 1.1:1. Incidence of blindness increases with age. 
Large number of patients is having preventable or treatable cause of blindness. Incidence of blindness was more in rural areas and in low socioeconomic population.

Blindness was more common in illiterate and less educated population \& had a significant relative risk (1.5) for development of blindness as compare to educated group. Incidence of blindness was more in farmers and labourers because they are not aware of various treatment facilities available.

Most common cause of blindness was cataract (49.4) followed by corneal blindness. Blindness is a major problem in community; however $80 \%$ of blindness can be prevented if proper intervention is done on time.

Blind patient's rehabilitation should be planned and government should offer some help for this.

However there is still a problem of social rejection of the blinds. More efforts are needed on the part of society and government agencies to recognise this problem, so that better results can be achieved by timely intervention.

It will also decrease social and economic burden on country.

Funding: Nil

Conflict of interest: Nil

Permission from IRB: Yes

\section{References}

1. Global Data on Blindness Reproduced by permission of WHO from: Global Data on Blindness, Thylefors B, Négrel A-D, Pararajasegaram R, Dadzie K Y. Bulletin of the World Health Organization 1995.page no 1

2. The prevention of blindness. Report of a WHO Study Group. Geneva, World Health Organization, 1973 (WHO Technical Report Series, No. 518).
3. International statistical classification of diseases and related health problems: tenth revision. Geneva, World Health Organization, 1992, 456-457

4. Kuppuswamy socioeconomic scale (Urban, 1976)(1)

5. Dandona R, Dandona L, Kovai V, Giridhar P, Prasad MN, SrinivasM. Indian J Ophthalmol. 2002 Jun;50(2):14555.

6. Vijaya L, George R, Arvind H, Baskaran M, Raju P, Ramesh SV, Paul PG, Kumaramanickave G, McCarty C. Prevalence and causes of blindness in the rural population of the Chennai Glaucoma Study. Br J Ophthalmol. 2006 April; 90(4): 407-410.

7. Venkata G, Murthy S, Gupta SK, Bachani D, Jose R, John N. Current estimates of blindness in India. Br J Ophthalmol, 89, 257-260.

8. Dandona R, Dandona L Review of findings of the Andhra Pradesh Eye Disease Study: policy implications for eye-care services Indian J Ophthalmol. 2001 Dec;49(4):215-34.

9. Dandona R, Dandona L, Srinivas M, Giridhar P, Prasad MN, Vilas K, McCarty CA, Rao GN Moderate visual impairment in India: the Andhra Pradesh Eye Disease Study Br J Ophthalmol. 2002 April; 86(4): 373377

10. Khanna RC, Marmamula S, Krishnaiah S, Giridhar P, Chakrabarti S, Rao GN. Changing trends in the prevalence of blindness and visual impairment in a rural district of India: Systematic observations over a decade Indian J Ophthalmol. 2012 Sep-Oct; 60(5): 492-497.

11. Thylefors B, Négrel AD, Pararajasegaram R, Dadzie KY Global data on blindness.Bull World Health Organ. $1995 ; 73(1): 115-21$. 
12. Nirmalan PK, Tielsch JM, Katz J, Thulasiraj RD, Krishnadas R, Ramakrishnan R, Robin AL. Relationship between Vision Impairment and Eye Disease to Vision-
Specific Quality of Life and Function in Rural India: The Aravind Comprehensive Eye Survey ; Invest. Ophthalmol. Vis. SSci. July 2005 vol. 46 no. 7. 2308-2312

\section{How to cite this article?}

Sharma B, Gupta R, Anand R, Rajput M. Demographic Profile of Blindness in Patients attending Tertiary Eye Care Centre in Central India. Int J Med Res Rev 2013;1(4):149-155. doi:10.17511/ijmrr.2013.104.02 